This item was submitted to Loughborough's Research Repository by the author.

Items in Figshare are protected by copyright, with all rights reserved, unless otherwise indicated.

\title{
Supergen SuperSolar: Photovoltaic materials and devices
}

PLEASE CITE THE PUBLISHED VERSION

http://dx.doi.org/10.1016/j.vacuum.2017.02.001

\section{PUBLISHER}

(c) Elsevier

VERSION

AM (Accepted Manuscript)

\section{PUBLISHER STATEMENT}

This work is made available according to the conditions of the Creative Commons Attribution-NonCommercialNoDerivatives 4.0 International (CC BY-NC-ND 4.0) licence. Full details of this licence are available at: https://creativecommons.org/licenses/by-nc-nd/4.0/

\section{LICENCE}

CC BY-NC-ND 4.0

\section{REPOSITORY RECORD}

Isherwood, Patrick J.M.. 2019. "Supergen Supersolar: Photovoltaic Materials and Devices". figshare. https://hdl.handle.net/2134/24417. 


\section{Supergen SuperSolar: Photovoltaic Materials and Devices}

\section{Guest editor:}

Patrick Isherwood

CREST

Holywell Park

Wolfson School

Loughborough University

Loughborough

Leicestershire

LE11 3TU

The growth in solar module production has been spectacular over the past two decades. Annual year on year growth has been an astonishing 35\% compound. Grid parity is being achieved in many important markets and once subsidies are no longer required, the market is expected to grow even more strongly. While silicon continues to retain its position as the leading installed technology, thin film devices have shown remarkable advances in both efficiency and cost reduction. Photovoltaics is consequently not only a thriving multi-billion dollar industry, but also a hugely exciting and increasingly important area of research.

Supergen SuperSolar Energy Hub is the primary EPSRC-funded project for photovoltaics research in the UK. It provides financial support as well as a means for collaboration between the various UK university research groups working in photovoltaics along with key industrial partners, ensuring that the UK retains its position as a leader in solar energy research and development. The following papers showcase some of the research being undertaken by SuperSolar Hub members including materials development and implementation, modelling and module characterisation. 